DOI: $10.2478 / \mathrm{v} 10025-009-0010-0$

\title{
Changes of the nutrient loads of the Odra River during the last century - their causes and consequences
}

\author{
Horst BEHRENDT ${ }^{l)}$, Dieter OPITZ ${ }^{1)}$, Agnieszka KOLANEK ${ }^{2)}$, \\ Rafalina KOROL ${ }^{2)}$, Marzenna STROŃSKA ${ }^{2)}$
}

\author{
1) Leibniz Institute of Freshwater Ecology and Inland Fisheries, Müggelseedamm 310, 12587 Berlin, \\ Germany; e-mail: behrendt@igb-berlin.de \\ 2) Institute of Meteorology and Water Management, ul. Parkowa 30, 51-616 Wrocław, Poland
}

\begin{abstract}
Nutrient emissions by point and diffuse sources and their loads were estimated for the Odra catchment over the time period of the last 50 years by means of the model MONERIS. For nitrogen a change of the total emissions from $38 \mathrm{kt} \cdot \mathrm{a}^{-1} \mathrm{~N}$ in the mid of $1950 \mathrm{~s}$ a maximum of $105 \mathrm{kt} \cdot \mathrm{a}^{-1}$ $\mathrm{N}$ in the early $1980 \mathrm{~s}$ and a recent value of about $84 \mathrm{kt} \cdot \mathrm{a}^{-1} \mathrm{~N}$ were estimated for the total Odra Basin. The share of the point source discharges on the total $\mathrm{N}$ emissions varied between $24 \%$ (1955) and $35 \%$ (1995). The emissions from groundwater and tile drained areas represent the dominant pathway (37-56\% of total $\mathrm{N}$ emissions) during all investigated time periods. Emissions from tile drained areas increased from the mid of 1950 s to end of 1980 s by a factor of 20 and reached in this period the same amount as emissions by groundwater. For phosphorus the emissions changed from $4 \mathrm{kt}^{-1} \mathrm{a}^{-1} \mathrm{P}$ in 1955 to $14 \mathrm{kt} \cdot \mathrm{a}^{-1} \mathrm{P}$ in 1990 and a recent level of $7 \mathrm{kt} \cdot \mathrm{a}^{-1} \mathrm{P}$. Point source discharges caused between 36 to $66 \%$ of total $\mathrm{P}$ emissions and represent the dominant pathway for all investigated time periods. Erosion and discharges from paved urban areas and sewer systems was the dominant diffuse pathway of the total P emissions into the river system. The comparison of calculated and observed nutrient loads for the main monitoring stations along the Odra River shows that the average deviation is $12 \%$ for total phosphorus (1980-2000) and 15\% for dissolved inorganic nitrogen (1960-2000). From the analysis it can be concluded that the present load of dissolved inorganic nitrogen (DIN) and total nitrogen (TN) of the Odra into the Baltic Sea is about 2.3 times higher than in the mid of 1960s. The maximum DIN load (1980s) was more than 3 times higher than in the 1960s. The change of the total

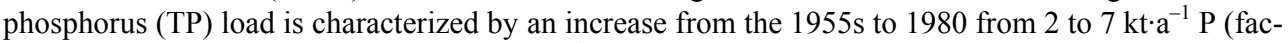
tor 2.6). Around 2000 the TP load was $4 \mathrm{kt}^{-\mathrm{a}^{-1}}$ which is only the double of the level of the $1955 \mathrm{~s}$.
\end{abstract}

Key words: Odra River, Baltic Sea, diffuse sources, point discharges, GIS, load, nutrient emissions, retention, long-term changes

\section{INTRODUCTION}

The Odra River system drains an area of $118,600 \mathrm{~km}^{2}$ which is approximately $6.8 \%$ of the Baltic Sea basin. 15.5 Mio. people are living within the Odra catch- 
ment representing about $19 \%$ of the total population of the Baltic Sea basin. The share of the Odra to total discharge into the Baltic Sea is only about $3.7 \%$. These few numbers illustrate the importance of the Odra River system for the Baltic Sea ecosystem. From the high portion of population and the low share to total discharge it can be assumed that the Odra is one of the main sources of pollution of the Baltic Sea due to high concentrations of nutrients and other substances. Beside the fact that observations in the last decade show a substantial reduction of the nutrients loads of the Odra, it is important to clarify what the sources of the nutrient fluxes within this river system are and what the causes are for these changes.

Previous studies on nutrient input into the Odra River (TONDERSKI, 1997; BEHRENDT et al., 1999; BEHRENDT and DANNOWSKI, 2005) have already identified the important sources, pathways, stocks and sinks of nutrients within the Odra catchment, but these studies were limited regarding the resolution in space (number of sub-catchments) and the analysed time periods.

Information on long-term changes of the nutrient loads from rivers to the ocean is important as ecological changes in the sea can be clarified. Because measurements of nutrient concentrations in the river systems are often only available for the last decades, loads of the past can only be quantified by modelling. HUMBORG et al. (2000) tried the first time to speculate on the changes of the load in the Odra from the 1950's to the 1990's and found that the increase of the nitrogen and phosphorus load of the Odra to the Szczecin Lagoon should be by a factor of 7 (P) to 10 (N). But the used model is very simple, because the authors assumed that the load of the Odra is proportional only to the changes of the application rates of mineral fertilizers. As shown by BEHRENDT and DANNOWSKI (2005) this assumption is far from the reality, because the large influence of other diffuse and point sources and the transfer along the different pathways was neglected. BEHRENDT and DANNOWSKI (2005) present a harmonized database and applied different model approaches for the total area of the Odra Basin and 42 sub-catchments. The nutrient emissions from point and diffuse sources into the whole Odra River system were estimated for the period 1993-1997.

With help of this established database and the model MONERIS (BEHRENDT et al., 2002) an attempt for the reconstruction of the nutrient emissions into the Odra River system is presented here for the time period from the $1955 \mathrm{~s}$ to $2000 \mathrm{~s}$. The aim was to compare the model results with the existing load data and to identify the causes for the changes of the nutrient loads of the Odra into the Baltic Sea in the last decades. Furthermore, it should be tested whether it is possible to reconstruct the nutrient loads and sources of nutrient emissions to the river system of the past. This is important for the calculation of scenarios with potential future load changes, because a model, which does not reflect the historical changes, cannot be applied for the simulation of possible changes in the future. A similar reconstruction was already done by BEHRENDT et al. (2005) for the Danube River system. 


\section{DATABASE AND METHODS}

\section{THE APPLIED MODEL}

The model MONERIS was applied to estimate the nutrient inputs by point and diffuse sources via various pathways in river basins of the Odra. The model is driven by data of river flow and a huge set of geo-referenced data stored in a geographical information system (GIS), which includes digital maps and extensive statistical information. MONERIS was applied in the last years for many European river systems (e.g. Axios, Elbe, Danube, Daugava, Po, Rhine and Vistula) (BEHRENDT, 2004; BEHRENDT et al., 2005; SCHREIBER et al., 2005b) and was also already applied for the Odra River basin (BEHRENDT and DANNOWSKI, 2005) but with a lower resolution and only for the time period 1993-1997.

Whereas point emissions from wastewater treatment plants and industrial sources are directly discharged into the rivers, diffuse emissions into surface waters are caused by the sum of different pathways, which are realised by separate flow components (Fig. 1). This separation of the components of diffuse sources is necessary, because nutrient concentrations and relevant processes for the pathways are mostly very different.

Consequently, seven pathways are considered within the MONERIS model:

- point sources,

- atmospheric deposition,

- erosion,

- surface runoff,

- groundwater,

- tile drainage,

- paved urban areas.

Along the pathway from the source of the emission into the river substances are governed by manifold processes of transformation, retention and loss. Knowledge of these processes is necessary to quantify and to predict nutrient emissions into the rivers in relation to their sources.

GIS use allows a regionally differentiated quantification of nutrient emissions into river systems. In contrast to a former study (BEHRENDT and DANNOWSKI, $2005)$ the calculations were not only made for 46 large sub-basins of the Odra.

Altogether the MONERIS model was applied to 484 different river catchments within the Odra basin for the time period 1998-2002 and former periods (Fig. 2). The spatial resolution was especially high for the Nysa Łużycka one of the major tributaries of the Odra. According to the guidelines of the Water Framework Directive (WFD) this catchment was subdivided into 132 sub-catchments with a mean size of $32 \mathrm{~km}^{2}$ (min. $1.5 \mathrm{~km}^{2}$, max. $142 \mathrm{~km}^{2}$ ) which corresponds nearly to the number of water bodies with this river system. For the remaining part of the 


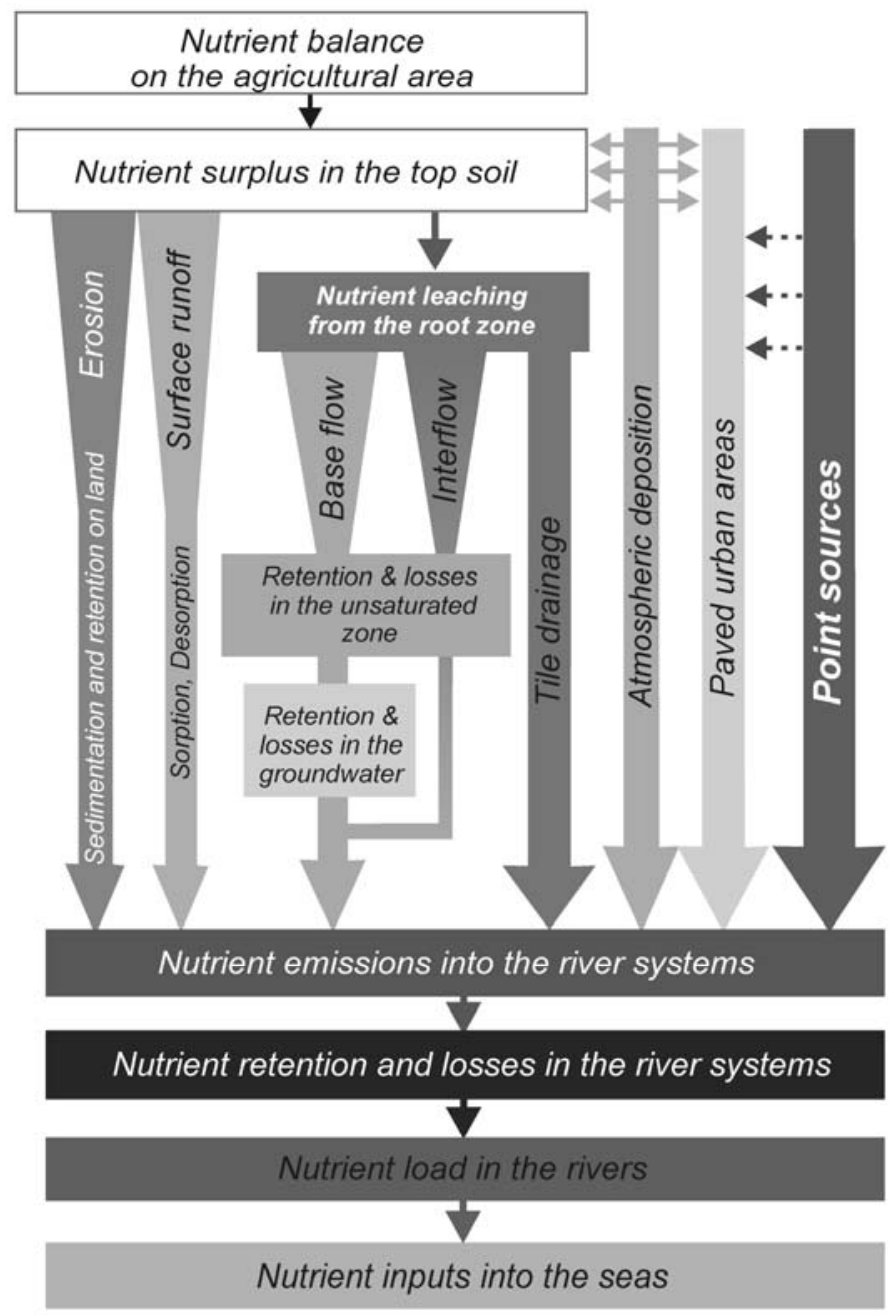

Fig. 1. Pathways and processes within MONERIS

Odra the mean size of the investigated sub-catchments was $326 \mathrm{~km}^{2}$ (min. $1 \mathrm{~km}^{2}$, max. $1269 \mathrm{~km}^{2}$ ).

Besides the nutrient emissions of the individual sub catchments the load of total phosphorus and total nitrogen as well as dissolved inorganic nitrogen was estimated from the emissions by means of the retention sub models of MONERIS (BEHRENDT and OPITZ, 2000). Data of 39 monitoring stations was used for the evaluation of the calculation results. Regarding long term changes the measurements of three locations (upper Odra at Frankfurt/Oder; Warta at Gorzów and total Odra at Schwedt and Krajnik Dolny) was taken into account. 


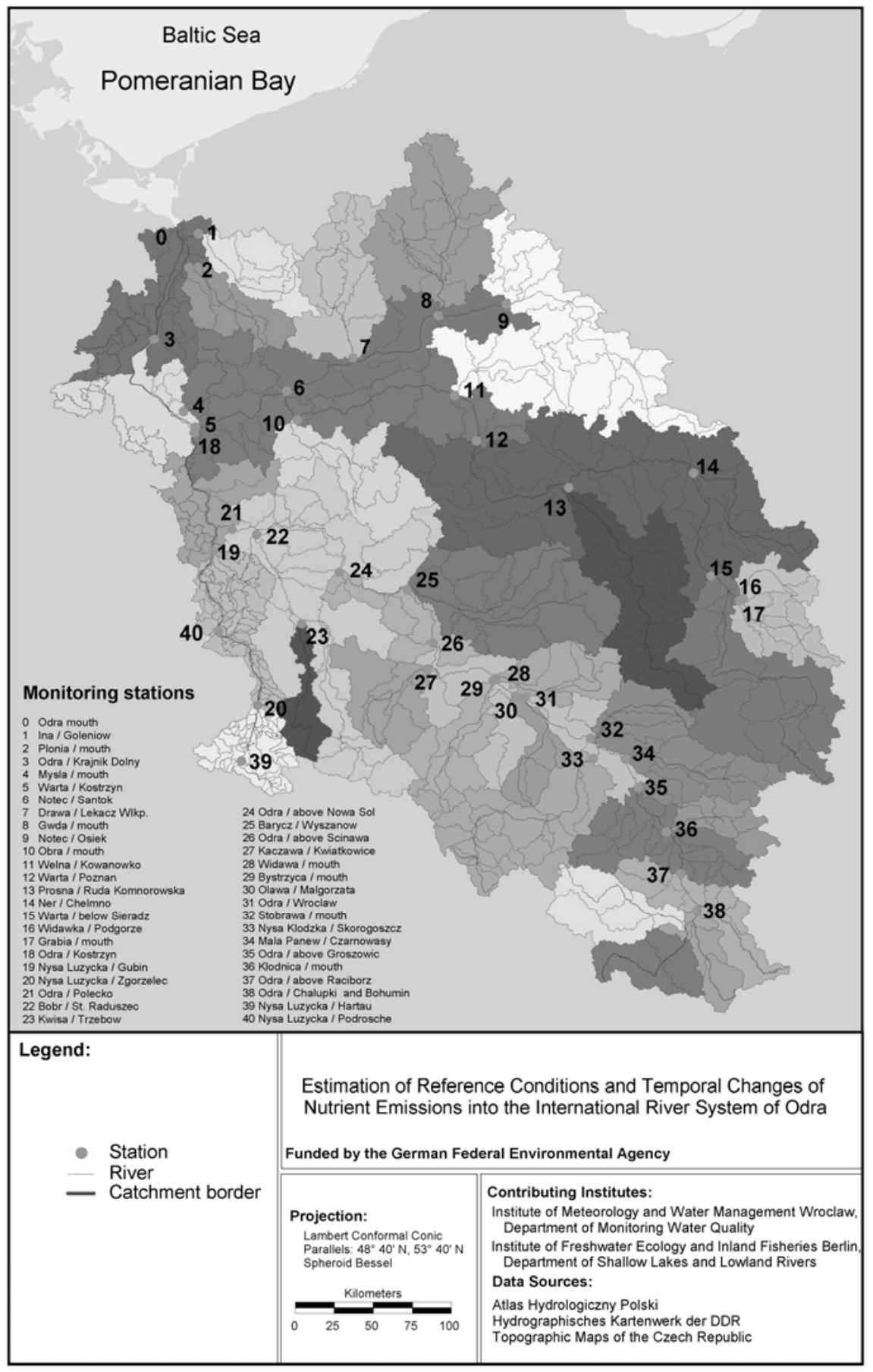

Fig. 2. Investigated sub catchments in the Odra basin and location of monitoring stations 


\section{INPUT DATA ON LONG-TERM CHANGES}

To model changes of the nutrient emissions and loads the database was used for the state in 2000 as described by BEHRENDT and DANNOWSKI (2005).

Changes of the main human effects on the nutrient emissions are taken into account as time series for the Odra. Official statistics of the individual countries and the FAO (FAOSTAT, 2004) were used for the description of the development of population and agricultural area as well as fertilizer application, livestock numbers and harvested crops. The nutrient surplus on agricultural area was estimated according to the OECD method (OECD, 1997). As shown in Figure 3 the development of the $\mathrm{N}$-surplus in agriculture was similar in all three countries. An increase from the 1950s to the mid 1970s is followed by a period of nearly constant level and a substantial decrease within the years 1989 to 1992. Since the mid of the 1990s the N-surplus is slightly increasing in Germany and Poland and stable in Czech Republic. The level of N-surplus was up to 1990 the highest in German part of the Odra. For Poland where the main part of Odra is located the N-surplus was about 50\% lower than in Germany.

The database for the connection of people to sewer systems and waste water treatment plants (WWTPs) was derived by statistical data for the German countries, Poland and Czech Republic.

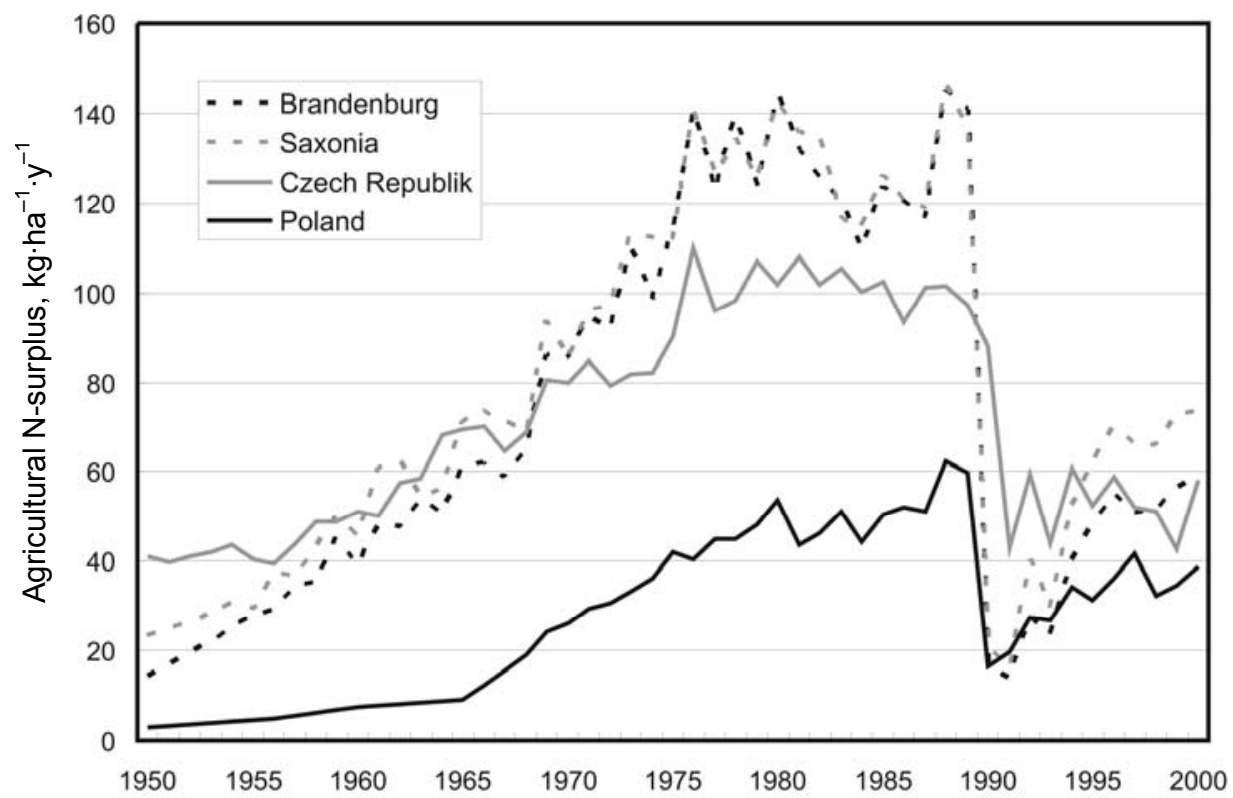

Fig. 3. Changes of nitrogen surplus on agricultural areas of the Polish, German and Czech part of the Odra basin from 1950 to 2000 
Table 1 and 2 show the changes of the main indicators for the development within the countries of the Odra basin from 1955 to 2000.

Table 1. Changes of the population in the Odra basin from 1960 to 2000 (data according to FAOSTAT data (2004), DE represents the data of Brandenburg and Saxionia according to Genesis (2004), all administrative data weighted by the portion of population in the Odra basin for the period $1998-2000$

\begin{tabular}{l|r|r|r|r|r|r|r|r}
\hline \multirow{2}{*}{ Country } & 1955 & 1960 & 1970 & \multicolumn{1}{|c|}{1980} & 1985 & 1990 & 1995 & 2000 \\
\cline { 2 - 9 } & \multicolumn{7}{|c}{1000 Inh. } \\
\hline CZ & 1227 & 1282 & 1342 & 1429 & 1446 & 1457 & 1461 & 1461 \\
PL & 9498 & 10948 & 11372 & 12386 & 12952 & 13269 & 13464 & 13464 \\
DE & 463 & 681 & 676 & 666 & 656 & 633 & 626 & 626 \\
Total & 11188 & 12912 & 13391 & 14480 & 15055 & 15359 & 15550 & 15550 \\
\hline
\end{tabular}

Table 2. Relative changes of the agricultural area in the Odra countries from 1955 to 2000 (data according to FAOSTAT data (2004), DE represents the data of Brandenburg and Saxonia according to Genesis (2004)

\begin{tabular}{l|c|c|c|c|c|c|c}
\hline \multirow{2}{*}{ Country } & 1955 & 1965 & 1975 & 1985 & 1990 & 1995 & 2000 \\
\cline { 2 - 8 } & \multicolumn{7}{|c|}{$\%$} \\
\hline CZ & 122.7 & 119.0 & 111.8 & 102.1 & 100.8 & 100.1 & 100.0 \\
PL & 115.9 & 114.0 & 108.5 & 100.5 & 100.2 & 101.0 & 100.0 \\
DE & 108.2 & 106.1 & 104.1 & 101.7 & 100.4 & 100.0 & 100.0 \\
\hline
\end{tabular}

For the development of waste water treatment for the individual countries it was assumed that existing WWTPs were equipped only with mechanical treatment in 1955. The change of the nutrient elimination of WWTPs for the individual countries was estimated by the multiplication of the elimination rates with the portion of the WWTPs with primary, secondary and tertiary treatment.

For the description of the changes of the specific $\mathrm{P}$ emissions of people and industrial indirect discharges into the sewer systems due to the changing use of phosphorus in detergents the published data was used according to SCHMOLL (1998) and BEHRENDT (1994). For Poland and Czech Republic we used the same trend as for Eastern Germany from 1955 to 1990. For the periods 1995 and 2000 the data published by BEHRENDT and DANNOWSKI (2005) was taken into account.

\section{RIVER NUTRIENT LOADS}

For the calculation of nutrient loads the data sets for 39 monitoring crosssections of the subbasins are used (Fig. 2). For each of the investigated subbasins the overall volume of nutrients and heavy metals is calculated according to the 
equation 1 for each year. This method for calculation of load is also the favoured method of OSPAR (1996) for calculation of loads into the North Sea.

$$
L_{y}=a \frac{Q_{y}}{\sum_{i=1}^{n} q_{i}} \sum_{i=1}^{n} q_{i} c_{i}
$$

with

$L_{y} \quad$ - annual load, $\mathrm{t} \cdot \mathrm{a}^{-1}$

a - unit conversion factor;

$n$ - number of data;

$Q_{y}-$ mean annual flow, $\mathrm{m}^{3} \cdot \mathrm{s}^{-1}$;

$q_{i} \quad$ measured flow, $\mathrm{m}^{3} \cdot \mathrm{s}^{-1}$

$c_{i}$ - measured concentration, $\mathrm{mg} \cdot \mathrm{l}^{-3}$.

From the annual values, the mean load for the studied time periods is estimated according to equation 2 :

$$
L_{P}=\frac{1}{p} \sum_{i=1}^{p} L_{Y}
$$

with

$L_{p}$ - average annual nutrient load in the studied period, $\mathrm{t} \cdot \mathrm{a}^{-1}$;

$p-$ unit conversion factor.

The observed discharges at the stations for the different time periods were used as input data to adjust the model to the flow conditions for the individual time periods. Additionally, all calculations were repeated with the long-term discharges (average discharges for the stations over all time periods) to distinguish between the effects of the changing hydrology and changes of human activities within the catchments.

\section{RESULTS AND DISCUSSION}

THE STATE OF THE NUTRIENT EMISSIONS IN THE PERIOD 1998-2002

The results of estimating the nutrient emissions into the Odra River and the contributions by pathways and by sources are presented for the period 1998-2002 in Table 3 and in Figure 4. 
Table 3. Nutrient emissions by point and diffuse sources into the Odra basin in the period 1998-2002

\begin{tabular}{cc|c|c|c|c|c|c|c|c}
\hline & & $\mathrm{E}_{\text {deposition }}$ & $\begin{array}{c}\mathrm{E}_{\text {surface }} \\
\text { runoff }\end{array}$ & $\begin{array}{c}\mathrm{E}_{\text {tile }} \\
\text { drainage }\end{array}$ & $\mathrm{E}_{\text {erosion }}$ & $\begin{array}{c}\mathrm{E}_{\text {ground }} \\
\text { water }\end{array}$ & $\mathrm{E}_{\text {urban areas }}$ & $\begin{array}{c}\mathrm{E}_{\text {point }} \\
\text { discharges }\end{array}$ & Sum \\
\hline Phosphorus & $\mathrm{t} \mathrm{P} \cdot \mathrm{y}^{-1}$ & 44 & 114 & 147 & 1517 & 907 & 3190 & 1140 & 7059 \\
& $\%$ & 0.6 & 1.6 & 2.1 & 21.5 & 12.8 & 45.2 & 16.2 & 100.0 \\
\multirow{2}{*}{ Nitrogen } & $\mathrm{t} \mathrm{N} \cdot \mathrm{y}^{-1}$ & 1500 & 5500 & 17900 & 2100 & 27900 & 22600 & 6200 & 83700 \\
& $\%$ & 1.8 & 6.6 & 21.4 & 2.5 & 33.3 & 27.0 & 7.4 & 100.0 \\
\hline
\end{tabular}

$\mathrm{E}_{\text {deposition }}-$ nutrient emissions via atmospheric deposition, $\mathrm{E}_{\text {surface runoff }}-$ from surface runoff, $\mathrm{E}_{\text {tile drainage }}-$ nutrient emissions via tile drainage, $\mathrm{E}_{\text {erosion }}-$ nutrient emissions by erosion, $\mathrm{E}_{\text {groundwater }}-$ nutrient emissions via groundwater, $\mathrm{E}_{\text {urban areas }}-$ nutrient emissions from urban areas, $\mathrm{E}_{\text {point discharges }}-$ nutrient emissions from point sources.

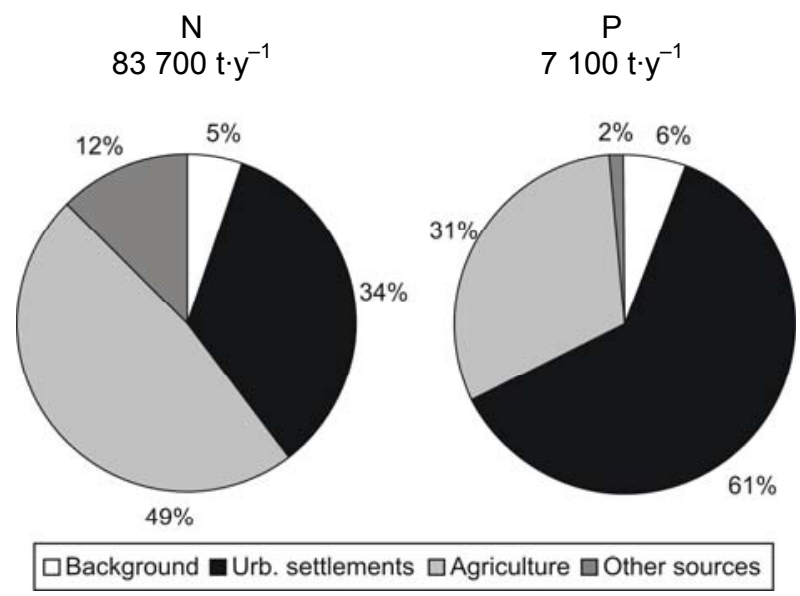

Fig. 4. Nutrient inputs from sources of human activities for the total Odra basin in the time period 1998-2002

Nitrogen emissions into the river basin of the Odra were about $83.7 \mathrm{kt} \cdot \mathrm{a}^{-1}$ in the period 1998-2002. As the main sources of nitrogen emissions, point sources $(27 \%)$, groundwater $(33 \%)$, and tile drainage $(21 \%)$ were identified. The contribution of the remaining pathways to the total nitrogen emission is only about $19 \%$. From the total nitrogen emissions within the Odra basin $79 \%$ have been addressed to Poland, $14 \%$ to the Czech Republic, and $7 \%$ to Germany.

The total phosphorus emissions into the Odra river basin were about $7.1 \mathrm{kt} \cdot \mathrm{a}^{-1}$ in the period 1998-2002. Point discharges are the dominant pathway for phosphorus inputs into the river system of the Odra. This pathway represents about $45 \%$ of the total $\mathrm{P}$ emission. Erosion (21\%) and urban areas (16\%) are the main diffuse $\mathrm{P}$ sources in the Odra basin. The remaining pathways contributes together only to about $17 \%$ of the total $\mathrm{P}$ emissions. The Polish part of the Odra basin generates 
$84 \%$ of the $\mathrm{P}$ emissions. A percentage of $11 \%$ and $5 \%$ of the $\mathrm{P}$ emissions is attributed to the Czech and German parts of the Odra basin, respectively.

If the natural background is calculated and the nutrient emissions are classified according to the ranges of human activities the portion of these activities at the total nutrient emissions can be calculated. This is shown in Figure 4.

It was found for the total Odra that between 5 and $6 \%$ of the present total nutrient emissions are only due to natural background. Whereas the agricultural activities (48\%) are the dominant source for nitrogen followed by the point and diffuse discharges from urban settlements $(34 \%)$ the phosphorus emissions of point and diffuse sources from urban settlements are responsible for $61 \%$ of the total emissions and agriculture for $31 \%$. For nitrogen the other diffuse emissions are not to neglect. This is the nitrogen emissions which would occur, if only the present NOx-deposition to the land and the surface waters would be the source for nitrogen emissions into the surface waters within the total area of the river system. The share of this source is $12 \%$.

Applying the retention functions of MONERIS for nitrogen and phosphorus, the loads within the sub-catchments of the Odra basin could be calculated and compared with the loads observed at 39 monitoring stations.

It was found that the mean deviation between the calculated and observed nitrogen loads was $27 \%$ for dissolved inorganic and total nitrogen. For phosphorus a mean deviation between calculated and observed loads of $21 \%$ was estimated for the 39 stations. The deviations between calculated and observed loads are in the same range as for other investigated river systems (BEHRENDT et al., 2003; SCHREIBER et al., 2005b).

The nutrient emissions into the river system of Odra are not unique. The spatial subdivision of the modelling into 484 sub-catchments allows the identification of areas where the pressures of nutrient emissions from different sources are higher or lower in comparison to the total average. This is shown in the Figures 5 for the regional distribution of total specific nitrogen and phosphorus emissions within the total Odra basin.

With exception of the sub-catchments which include large cities (e.g. Katowice, Wrocław, Łódź, Poznań and Szczecin) the total specific nitrogen emissions are the highest in the areas of consolidated rocks and in the central part of the Warta where the share of tiled drained areas is the highest. For both areas it is characteristically that the retention of nitrogen, mostly by denitirifcation is reduced, but this is due partly to natural conditions in the consolidated rock region and by human activities for the tile drained areas.

The regional distribution of the total phosphorus emission is characterized by very high levels for the subcatchments where discharges occur from WWTP and diffuse emissions from urban areas. For the rest of the Odra basin the total P emissions are in general clearly below $1 \mathrm{~kg} \cdot \mathrm{ha}^{-1} \cdot \mathrm{y}^{-1}$. 


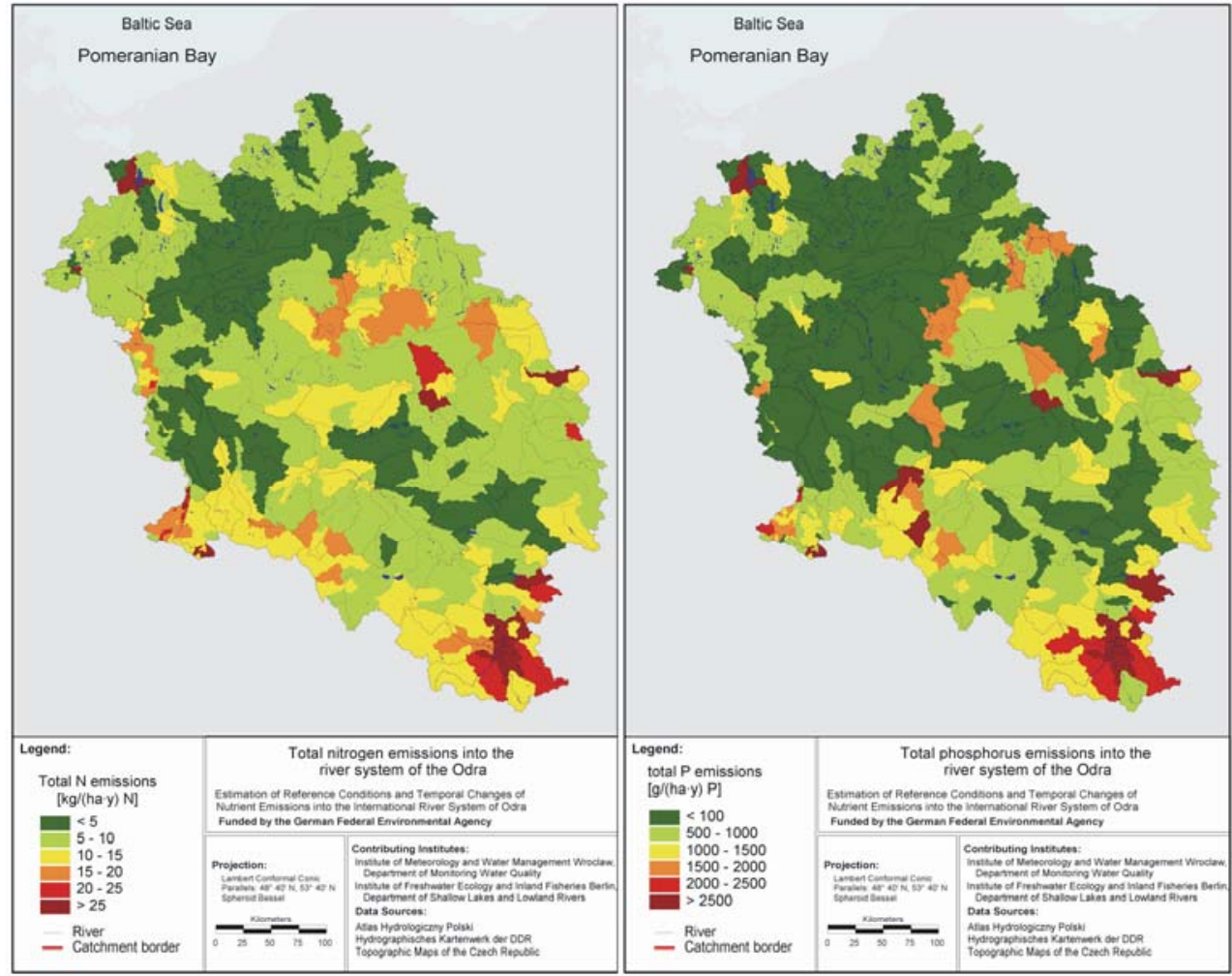

Fig. 5. Regional distribution of the total nitrogen (left) and phosphorus (right) emissions within the Odra basin in the time period 1998-2002

\section{CHANGES OF NUTRIENT EMISSIONS FROM POINT SOURCES}

In contrast to former studies one target of this study was the attempt to reconstruct the load situation in the Odra for former time periods. For this attempt the database was enlarged with regard to changes of the nutrient pollution (e.g. nitrogen surplus and phosphorus accumulation on agricultural land; tile drained areas; connection of population to sewers and waste water treatment plants, efficiency of WWTP in the past). The successful reconstruction of the historical changes of nutrient loads is an important precondition for an application of the model for the estimation of the nutrient loads depending on possible measure to reduce the emissions and loads.

Figure 6 gives a summarised overview on the temporal variation of the nutrient emissions into the Odra River system from individual pathways. For both nutrients the point source emissions increased from 1955 to 1990 by a factor of about $3.6(\mathrm{~N})$ and $8.6(\mathrm{P})$, respectively, and then decreased especially in the last 10 years. 


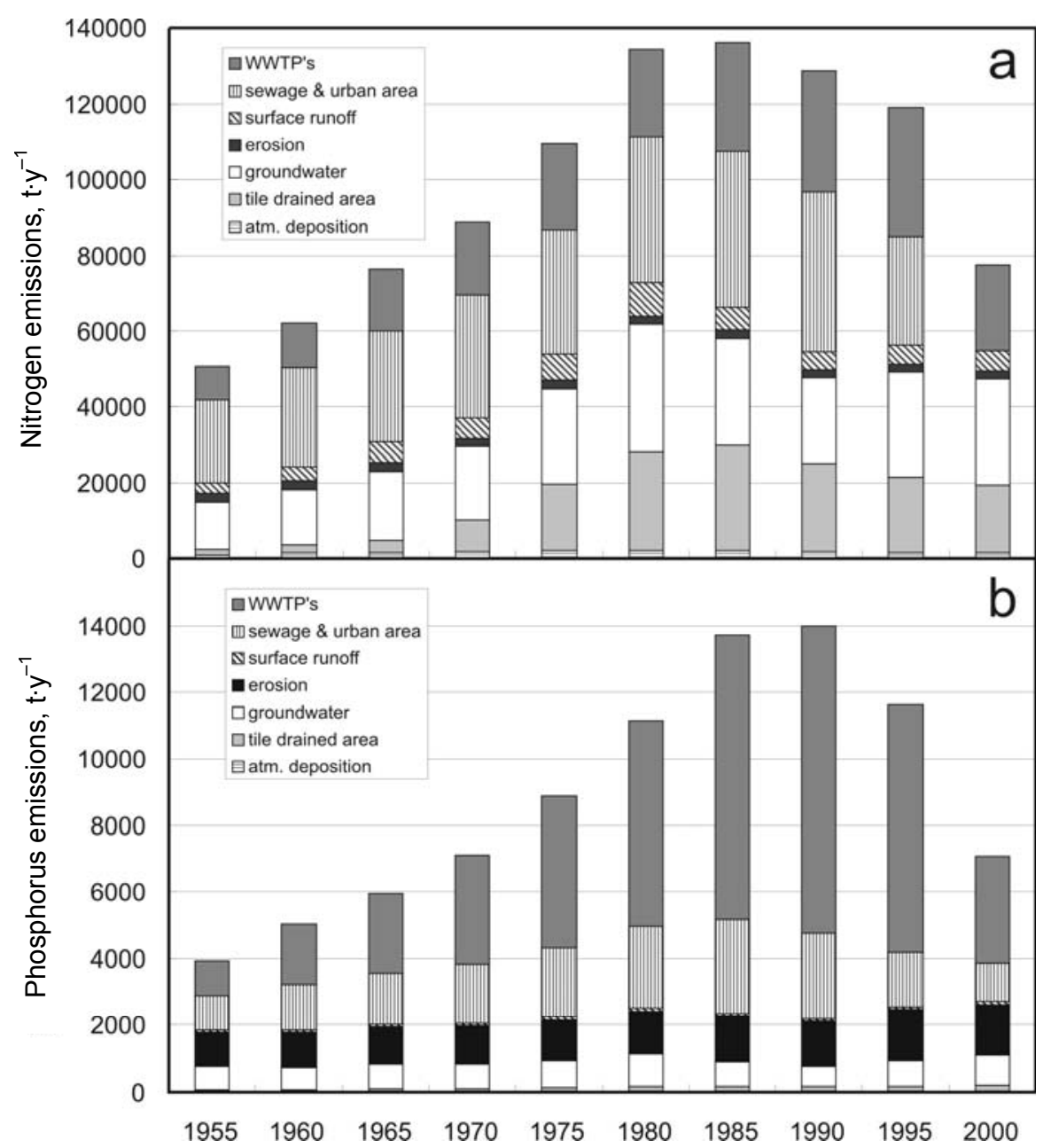

Fig. 6. Long term changes of the nitrogen (a) and phosphorus (b) emissions by pathways into the Odra River system upstream of the monitoring station Krajnik Dolny

The cause is for both nutrients the improvement of nutrient elimination in the WWTPs, but for phosphorus it is additional to take into account that the P used in detergents is practically reduced to zero in Germany and to a half in Poland and Czech Republic. The present $\mathrm{P}$ point source discharges are about $65 \%$ lower as in 1990 but still 200\% higher than in 1955.

Changes of the $\mathrm{N}$ point sources discharges in the Odra River Basin are mainly effected by the construction of sewer systems and the increasing removal efficiency in the recent years. The present $\mathrm{N}$ point source discharges decreased by about $30 \%$ in the 1990s but still exceed the level of the 1955 s by about $150 \%$. 


\section{CHANGES OF NUTRIENT EMISSIONS FROM DIFFUSE SOURCES}

According to Figure 6 the nitrogen emissions from diffuse sources have increased from the $1955 \mathrm{~s}$ to the 1980 s by a factor of 3 . In the 1990 s this pollution was decreasing but in the last three time periods the diffuse $\mathrm{N}$ emissions are nearly constant. The reason for this behaviour is on the one hand the different discharges in these time periods (see Figure 7) and the long residence times in the groundwater (see BEHRENDT and DANNOWSKI, 2005). The present emissions by diffuse $\mathrm{N}$-sources are about $24 \%$ below the maximum (1980) but about $133 \%$ higher than in the $1955 \mathrm{~s}$.

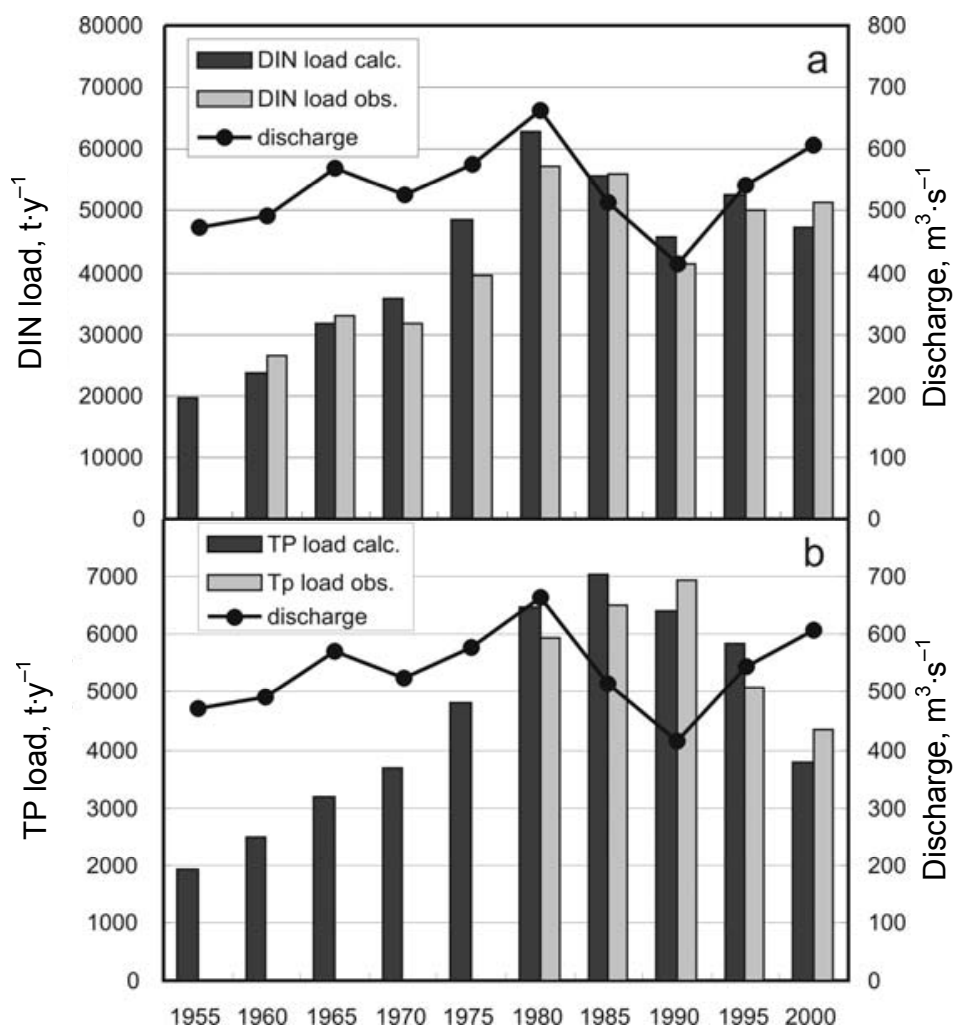

Fig. 7. Long term changes of the calculated and observed loads of dissolved inorganic nitrogen and total phosphorus for the Odra River at the station Krajnik Dolny

Compared to nitrogen the phosphorus emissions from diffuse sources were relatively constant. If the uncertainties in the database are taken into account the present level of $\mathrm{P}$ emissions into the Odra River system from diffuse sources is probably $40 \%$ higher as in the 1955 s. 
The maximum of total emissions for the river system of Odra occurred in 1980 for nitrogen with $106000 \mathrm{t} \cdot \mathrm{y}^{-1}$ and in 1990 for phosphorus with $14000 \mathrm{t} \cdot \mathrm{y}^{-1}$ (see Fig. 6 - showing the trend of nutrient emissions for the Odra upstream of the station Krajnik Dolny). According to Figure 6 total emissions from 1955 to the maximum increased by a factor of $2.5(\mathrm{P})$ and $1.8(\mathrm{~N})$. Compared to the maximum the reduction of the total emissions in the $1990 \mathrm{~s}$ is $21 \%$ for nitrogen and $50 \%$ for phosphorus. The present level of the total nutrient emissions is about $78 \%(\mathrm{P})$ and $120 \%(\mathrm{~N})$ higher than in the $1955 \mathrm{~s}$.

The changes of the total nutrient emissions into the Odra River system are the result of large changes of the share of the individual pathways in the total emissions (Fig. 6). In the $1955 \mathrm{~s}$ the nitrogen emissions from groundwater $(33 \%)$ were the dominant pathways followed by point sources (24\%) and urban areas (24\%). During the maximum emission period the emissions from tile drained areas and point discharges increased to about $(27 \%)$ whereas the share of groundwater and urban areas decreased to 27 and $9 \%$, respectively. The present situation is characterized once more by a dominance of emissions from groundwater (33\%) followed by the emissions from point discharges $(27 \%)$ and tile drained areas $(21 \%)$. The contribution of $\mathrm{N}$ emissions from atmospheric deposition direct to surface waters, surface runoff and erosion are of minor importance for all time periods.

For phosphorus the dominant pathway in the 1955 s was the point source discharges $(27 \%)$ followed by the emissions from urban areas $(27 \%)$ and erosion (25\%). In the late 1980 s the total $\mathrm{P}$ emissions were dominated to $66 \%$ from point discharges, and the portion of erosion and urban areas was reduced to $10 \%$ and $19 \%$, respectively. In the last investigated time period the point sources remained the major pathway ( $45 \%$ ) but due to the large reduction of point discharges the portion of erosion has increased to $22 \%$. Also for phosphorus the contribution of the other pathways (groundwater, tile drainage, atmospheric deposition) is of minor importance for the whole investigated time period.

\section{CHANGES OF NUTRIENT LOADS INTO THE ODRA RIVER}

The Figure 7 shows the results of the reconstruction of the nutrient loads for the Odra station at Krajnik Dolny (corresponding to Schwedt for the German site). For this station observed loads of dissolved inorganic nitrogen (DIN) and total phosphorus were also available back to the 1960 and 1980, respectively. Therefore the calculated and observed loads can be compared for $5(\mathrm{P})$ and $7(\mathrm{~N})$ different time periods. The figure illustrates that the model is able to calculate the changes of the nutrient loads in the past. The estimated model efficiency according to NASH and SUTCLIFFE (1970) was 0.96 for phosphorus and 0.86 for dissolved inorganic 
nitrogen (DIN). This corresponds to a deviation between calculated and observed loads of $12 \%(\mathrm{P}), 15 \%(\mathrm{DIN})$.

It was found that a substantial reduction of the load of total phosphorus $(40 \%$ compared to the time period 1985) was already reached. This is mainly due to the total or partial replacement of phosphorus used in detergents as well as the increasing efficiency of the P-elimination in WWTP's. These measures are the reason that P-discharges from point sources and urban areas were reduced to about $55 \% \mathrm{com}$ pared to the maximum level around 1990. On the other hand the agricultural sources of phosphorus emissions vary with the runoff. Therefore the P-emissions from agricultural sources were in the time period 1998-2002 about $11 \%$ higher than in the mid of 1980 s.

For nitrogen the calculated and the observed loads do not show a clear trend of reduction. This is due to two different tendencies. On the one hand the point and diffuse nitrogen emissions form urban settlements were decreasing but to a minor extent than for phosphorus (reduction: 30\% since mid of 1985s). The agricultural sources are also decreased but only by about $22 \%$ and strongly dependent on runoff conditions. This is surprising because the $\mathrm{N}$ surplus in agriculture showed a substantial decrease. The reasons for this phenomenon are the long residence times of water in the unsaturated zone and in the groundwater (on average about 25 years). That means that a certain part of the estimated agricultural nitrogen emissions in the period 1998-2002 is due to agricultural practices in the seventies and eighties.

\section{CONCLUSIONS}

The emissions and loads of nitrogen in the Odra basin in the period 1998-2002 are low in comparison to other river systems in Central Europe, which is mainly due to the high portion of the unconsolidated rock region in the total catchment area of the Odra. The same can be concluded for the diffuse P emissions in the Odra basin, whereas the level of point source emissions into the Odra is also now higher than in other rivers in Central Europe in the same time period (SCHREIBER et al., 2005a).

If the results of our analysis are compared with the assumptions of HUMBORG et al. (2000) it can be clearly shown that the long term changes of the nutrient loads were much lower. An increase of these loads from the 1950s to the 1990 s by a factor of $7(\mathrm{P})$ and $10(\mathrm{~N})$ seems is very unrealistically. This can be shown by the model results and the observed loads. From this it can be concluded that very simple assumptions on the interrelation between one driving force - HUMBORG et al. (2000) assumed that the changes of nutrient loads are proportional to the application of mineral fertilizers - and the nutrient loads in river systems are not able to describe the changes of the load in the past. For such studies an analysis of all 
sources of nutrient emissions into the river system and the retention in the surface waters is necessary.

The comparison of the long term trend of the nutrient emissions and loads of Odra and Danube (BEHRENDT et al., 2005) shows some similarities which can be described by the following:

- The changes of the nutrient emissions and loads are much larger than changes of simple indicators of human activities as population and land use (e.g. agricultural area).

- The changes of nutrient emissions and loads are mostly related to intensities of human activities as P-emissions per inhabitant before and after waste water treatment and nitrogen surplus in agriculture.

- The response of both river systems in relation to changes of P-emissions is fast due to the dominance of discharges from urban settlements in the past. These degree of the changes was in the last 10 years so strong that the P-loads (observed and calculated shows a clear decrease.

- The changes of the N-emissions were lower than for phosphorus. Due to this fact and the dominance of diffuse sources the decrease of the nitrogen load is in the range of the hydrological variations. Therefore an increase and decrease of the loads could be observed depending on the runoff conditions in the different periods.

- For river systems in Central and Eastern Europe the period 1988 to 1992 was characterised by low discharges. For following periods a slight increase of the nitrogen loads could be observed, because the increase in the runoff of the rivers was larger than the decrease of the emissions from human activities.

The results of the study show that the model MONERIS can be applied for the calculation of changing nutrient emissions and loads in the Odra with a spatial resolution which corresponds to the demand according the Water Framework Directive. Therefore as a next step the calculation of scenarios based on the demand for the implementation of the management plan seems to be possible. For this task the spatial resolution should be for the total Odra adapted to the official subdivision as already done in this study for the subcatchment of the Nysa Lużycka. Further the database according the smaller waste water treatment plants and the population connected to sewerage and WWTP as well as the situation regarding the existing sewer systems (combined and separate) should be increased. With regard to the calculation of the changes of ecological situation within the Szczecin Lagoon and the Baltic Sea the model results show that a reconstruction of historical changes is possible. But for the link to an ecosystem model of the Lagoon the temporal resolution for the nutrient loads have to be increased.

\section{Acknowledgements}

We would like to thank the German Federal Environmental Agency for funding the project. Further it is important for us to thank all of the institutions which have supported 
the project by supplying data and helpful discussions in the Czech Republic, Poland, and Germany.

\section{REFERENCES}

1. BeHRENDT H., 1994. Phosphor- und Stickstoffeinträge über punktförmige Quellen. In: Regional differenzierter Stickstoff- und Phosphateintrag in Fließgewässer im Bereich der ehemaligen DDR unter besonderer Berücksichtigung des Lockergesteinsbereiches. Eds. W. Werner, H.-P. Wodsak. Agrarspektrum 22: 137-164.

2. Behrendt H., Ley M., Korol R., Stronska-Kedzia M., Pagenkopf W., 1999. Point and diffuse nutrient emissions and transports in the Odra Basin and its main tributaries. Acta Hydrobiolgia et Hydrochimica 27: 274-281.

3. BeHREndT H., Opitz D., 2000. Retention of nutrients in river systems: Dependence on specific runoff and hydraulic load. Hydrobiologia 410: 111-122.

4. Behrendt H., Huber P., Kornmilch M., Opitz D., Schmoll O., Scholz G., Uebe R., 2002. Estimation of the nutrient inputs into river basins - experiences from German rivers. Regional Environemental Changes 3: 107-117.

5. Behrendt H., Bach M., Kunkel R., Opitz D., Pagenkopf W.-G., Scholz G., Wendland F., 2003. Quantifizierung der Nährstoffeinträge der Flussgebiete Deutschlands auf der Grundlage eines harmonisierten Vorgehens. UBA-Texte 82/03: 201.

6. BehrendT H., 2004. EUROpean CATchments, catchment changes and their impact on the coast. WP4 of the EUROCAT project: 65.

7. Behrendt H., DANNOwSKi R., 2005. Nutrients and heavy metals in the Odra River system. Weißensee Verlag, Berlin: 353.

8. Behrendt H., Schreiber H., van Gils J., Zessner M., 2005. Point and diffuse nutrient emissions and loads in the transboundary Danube river basin. II. Long term changes. Arch. Hydrobiol. Suppl. 158 (Large Rivers 16): 221-247.

9. FAOSTAT, 2004: http://faostat.fao.org/site/526/default.aspx.

10. Humborg C., Fennel K., Pastuszak M., Fennel W., 2000. A box model approach for a long-term assessment of estuarine eutrophication, Szczecin Lagoon, southern Baltic. Journal of Marine Systems 25: 387-403.

11. NASH J.E., SutCLIFFE J.V., 1970. River flow forecasting through conceptual models. Part 1. A discussion of principles. Journal of Hydrology 10: 282-290.

12. OECD, 1997. OECD national soil surface nutrient balances: 1985 to 1996. Explanatory notes. OECD Secretary, Paris: 16.

13. OSPAR (Oslo-Paris-Commission), 1996. Principles of the comprehensive study of riverine inputs and direct discharges (RID).

14. SCHMOLL O., 1998. Nährstoffeinträge aus kommunalen Kläranlagen in die Flussgebiete Deutschlands: Notwendigkeiten und Möglichkeiten ihrer weiteren Verminderung. Diplomarbeit, Technische Universität Berlin, Institut für Technischen Umweltschutz.

15. Schreiber H., Behrendt H., Constantinescu L.T., Cvitanic I., Drumea D., Jabucar D., Juran S., PATAKi B., Snishko S., Zessner M., 2005a. Nutrient emissions from diffuse and point sources into the River Danube and its main tributaries in the period 1998-2000. Results and problems. Water Science and Technology 51, 3-4: 283-290.

16. Schreiber H., Behrendt H., Constantinescu L.T., Cvitanic I., Drumea D., Jabucar D., Juran S., PAtaki B., Snishko S., Zessner M., 2005b. Point and diffuse nutrient emissions and loads in the transboundary Danube river basin - I. A modelling approach. Arch. Hydrobiol. Suppl. 158 (Large Rivers 16): 197-220.

17. TONDERSKI A., 1997. Control of nutrient fluxes in large river basins. Linköping Studies in Arts and Sciences: 157. 


\section{STRESZCZENIE}

\section{Zmiany ladunków biogenów w Odrze w ciągu ostatniego wieku - przyczyny i skutki}

Słowa kluczowe: GIS, tadunek, emisja azotanów, Morze Bałtyckie, Odra, retencja, źródła rozproszone, zmiany dtugoterminowe, zrzuty punktowe

Emisja składników biogennych ze źródeł punktowych i rozproszonych oraz ich ładunki w zlewni Odry zostały obliczone dla 50 ostatnich lat z wykorzystaniem modelu MONERIS. Emisja związków azotu w zlewni Odry zmieniała się od 38 $\mathrm{kt} \cdot \mathrm{r}^{-1} \mathrm{~N}$ w połowie lat 50 . XX w. do maksymalnie $105 \mathrm{kt} \cdot \mathrm{r}^{-1} \mathrm{~N}$ we wczesnych latach 80 . Udział zrzutów ze źródeł punktowych w całkowitej emisji azotu zmieniał się między 24\% (1955 r.) a 35\% (1995 r.). Emisja z wód gruntowych i obszarów zdrenowanych jest czynnikiem dominującym i stanowi 37-56\% całkowitej emisji azotu w analizowanym okresie. Emisja z obszarów zdrenowanych zwiększa się od połowy lat 50. do końca lat 80. 20 razy, osiagając taką samą wielkość jak emisja $\mathrm{z}$ wód gruntowych.

Emisja związków fosforu zmieniła się od $4 \mathrm{kt} \cdot \mathrm{r}^{-1} \mathrm{P}$ w $1955 \mathrm{r}$. do $14 \mathrm{kt} \cdot \mathrm{r}^{-1} \mathrm{P}$ w $1990 \mathrm{r}$., a ostatnio osiagnęła $7 \mathrm{kt} \cdot \mathrm{r}^{-1} \mathrm{P}$. Zrzuty ze źródeł punktowych stanowią od 36 do $66 \%$ całkowitej emisji fosforu i są dominującym czynnikiem w całym badanym okresie. Erozja oraz zrzuty zanieczyszczeń z obszarów miejskich to najważniejsze drogi dopływu związków fosforu ze źródeł obszarowych do rzeki.

Porównanie obliczonych oraz obserwowanych ładunków składników biogennych w głównych stanowiskach monitoringowych zlokalizowanych wzdłuż Odry, wskazuje, że średnie odchylenie wynosiło $12 \% \mathrm{w}$ przypadku fosforu całkowitego (1980-2000) i 15\% - azotu mineralnego (1960-2000). Po przeanalizowaniu wyników można wysnuć wniosek, że aktualny ładunek azotu mineralnego (DIN) i azotu całkowitego (TN) wnoszony z Odry do Morza Bałtyckiego jest około 2,3 razy większy niż w połowie lat 60 . Maksymalny ładunek DIN (1980 r.) był ponad 3 razy większy od tego z lat 60 . Zmiany ładunku fosforu całkowitego (TP) są charakteryzowane zwiększeniem wartości z $2 \mathrm{kt} \cdot \mathrm{r}^{-1} \mathrm{P}$ (1955 r.) do $7 \mathrm{kt} \cdot \mathrm{r}^{-1} \mathrm{P}$ (1980). Około $2000 \mathrm{r}$. ładunek TP wynosił $4 \mathrm{kt} \cdot \mathrm{r}^{-1}$, co jest wartością tylko dwukrotnie większą od stwierdzonej w $1955 \mathrm{r}$.

Reviewers:

Prof. Józef Koc

Prof. Stefan Pietrzak 